\title{
Cadmium puts UK village at risk
}

Cadmium, a light metal mined with with zinc, has been discovered in abnormally high amounts in stream sediment in the village of Shipham, the site of a zinc mine abandoned two hundred years ago. The Department of the Environment (DOE) has warned the villagers not to eat local produce and not to smoke and has initiated a $£ 70,000$ investigation to study the effects on health.

Levels of cadmium found in the soil varied from $11 \mathrm{ppm}$ to $998 \mathrm{ppm}$. The accepted safe level is less than $1 \mathrm{ppm}$. Serious cadmium poisoning occurred in Japan from 1962 to 1968 caused by levels of cadmium in rice paddies of $1-50 \mathrm{ppm}$ although there were other contributing factors in Japan that are not present in Shipham-such as dissolved cadmium in water.
Shipham water has been tested and is "absolutely safe" said Mr Denis Howell (a minister in the Department of Environment). "There is cause for concern but not for alarm. It is in nobody's interest to exaggerate the alarm" said Howell. Local residents have known for years that vegetables grow yellow in certain locations, and there is a local ailment - called "Shipham tummy" - which could be a sign of chronic cadmium exposure. Long term effects are poorly known but symptoms of cadmium poisoning are diarrhoea, vomiting, stomach pains and choking.

The high concentrations were discovered in the course of an Imperial College geochemical reconnaissance of England and Wales begun in 1967. The study took 50,000 stream sediments from tributary drainage over the whole country during a ten week period in 1969. A complementary sampling of soil and rock was undertaken in Shipham to test for the presence of elements in areas of poor drainage. The high cadmium count found in this survey was followed up by sampling garden soil in conjunction with researchers from the Westminister Hospital Medical School in Spring 1978. These results were released to the DOE last August.

Dr Ian Thornton, Geochemistry Department at Imperial College and participant in the original study says that Shipham is probably unique. Calamine, $\mathrm{ZnCO}_{3}$, was mined in Shipham whereas in other mines it was galena, zinc sulphide.

Joe Schwartz

\section{Biochemist challenges redundancy}

AN industrial tribunal currently underway in Manchester raises new questions on the power of granting agencies to make scientists redundant. Dr David Pillinger, FRIC, 39, a biochemist employed at the Christie Hospital in Withington near Manchester, is the first senior staff member of the National Health Service to be made redundant since 1948. Pillinger's case, brought to the tribunal with the aid of ASTMS, squarely confronts a complicated legal issue affecting thousands of scientific workers in the UK; who is their employer? Is it the agency that provides the money or the institution that does the hiring?

Pillinger was hired in 1962 by the Manchester Area Health Authority to do cancer research at the Christie Hospital. At that time there was no special category for research workers and Pillinger was engaged on the same basis as the clinical biochemists and physicists, with a permanent NHS contract, the funding coming from the British Empire Cancer Campaign. In this arrangement the Health Authority provides a permanent contract even though it does not provide the funds, with the understanding that the contract will be underwritten by the Authority should outside money dry up.

In 1972, Professor L. G. Lajtha, Director of Research in the Christie Hospital's Patterson Laboratory, attempted to bring all research workers under MRC short term contracts of three to five year duration. Pillinger refused to sign such a contract but eventually was persuaded in 1973 to take a post of unlimited duration on a block grant, a form of funding that covers several different projects. This was a hybrid contract in which the employer was still the Health Authority but the money and pay scales were set by the MRC. Says Pillinger, "There is no doubt, nor has it ever been questioned, that my employer is the Area Health Authority."

Nevertheless in June 1978, Pillinger was told by Lajtha that he was to be made redundant. In a letter from the MRC Lajtha was told that there was to be no reduction in funding for Pillinger's chemotherapy project but that the MRC did not feel "that Dr Pillinger should continue to be supported even though a senior scientist is needed". Pillinger pressed Lajtha for an explanation and in notes submitted to the tribunal quotes Lajtha as saying, "I doubt if we will ever be told, since the MRC is an autonomous body. It does not have to give account to anyhody for any of the decisions they take."

The Christie Hospital administration is supporting Pillinger. $\mathrm{Mr}$ D. C. Critchley, former Sector Administrator, was called by Pillinger's counsel, Ms Janet Smith, to testify last Monday. Lajtha, however, is critical of the hospital administration. Calling Pillinger's case a "purely administrative problem" I_ajtha feels that Pillinger's original contract was a case of "administrative irresponsibility" and that the old management should have made it clear that a scientists's employment must depend on the ebb and flow of grant money. Lajtha says that the MRC project grant renewal did not permit him to employ a Senior Grade Scientist but only a Grade 2 Scientist (equivalent to a Lecturer). When asked why he did not make representations on Pillinger's behalf to the MRC Lajtha said that he had already presented the case to the MRC and that they were "fully in the picture".

Behind the official language of dismissal and tribunal, however, lies a story of research conflict and scientific disagreement. In 1969 Pillinger returned from a two year stint at Columbia University in New York where he worked with Ernest Borek on tRNA modification by methylation. Pillinger began work on this line at the Christie Hospital and produced 12 publications in three years. In 1972 this project was terminated by the MRC. Lajtha requested that Pillinger start work on a model of cancer cell proliferation in which tissues were hypothesised to produce proliferation inhibitors. Pillinger's job was to isolate the putative inhibitors called chalones. The technique used cell extracts in water and the fraction of MW of around 1000 was observed to inhibit cell division. Pillinger was critical of this work and thinks that the results were artefacts. (The cell division assay used radioactive thymidine as a marker and Pillinger felt that the cell extract fraction found to inhibit division probably contains thymidine so that a decrease in thymidine uptake was an artefact of the preparation.) In 1974 Pillinger transferred to other work on cancer chemotherapy with Brian Fox, Head of Experimental Chemotherapy. It was on this project grant that the MRC found that Pillinger's services were no longer necessary.

Joe Schwartz 